\title{
Impact of Climate Change on Productivity of Tropical Rice-Wheat-Jute System under Long Term Fertilizer Management in Alluvial Soils
}

\author{
A.K. Singh", D. Barman, M.S. Behera, S.P. Mazumdar, A.R. Saha and D.K. Kundu \\ Crop Production Division, ICAR-Central Research Institute for jute and Allied Fibres \\ (CRIJAF), Barrackpore, Kolkata-700120, West Bengal, India \\ *Corresponding author
}

\begin{abstract}
A B S T R A C T
\end{abstract}
Variability in climate regimes of rainfall and temperature is a source of biotic and abiotic

Keywords

Climate variability,

Rice-wheat-jute production, Alluvial soils, Eastern India

Article Info

Accepted:

12 October 2018

Available Online:

10 November 2018 stresses in agricultural systems worldwide. This study examines seasonal and annual rainfall and temperature variability in rice, wheat and jute crop productivity for five decades (1972-2012) under long-term fertilizer experiment in alluvial soils of eastern India. The climatic variations and impacts were captured using a standardized precipitation index (SPI), diurnal temperature range (DTR) and crop productivity index (CPI). Overall, the SPI indicated the prevalence of frequent dry and wet periods and DTR recorded a decreasing trend. The multiple regression analysis identified a significant correlation between CPI, SPI and DTR accounting for yield variability in rice, wheat and jute. Winter wheat was affected most due to changing pattern of rainfall and night temperature. Impact of rainfall variability did not affect rice yield significantly but benefited jute productivity during summer season. Wheat production is at risk due to frequent drought and decreasing temperature. Research on climate smart agricultural practices through environmentally sound and economically feasible technologies is necessary to mitigate the adverse climatic conditions.

\section{Introduction}

Climate is one of the input factors in crop production and playing an important role in changing situations on agricultural productivity. A climatic change on agriculture has already been started showing its effect on the natural resource use and food security of farming community. Rainfall including ambient temperature and soil condition, help to determine the growth and yield of crop plants (Eze and Afolabi, 2013). The associated impacts of increased temperatures, altered pattern of rainfall and high frequency of damaging events like drought and floods, would probably unite to decrease yields and increase risks in agricultural productivity in different parts of the world (Sushila, 2001). Some studies show that the reduction in rainfall may decrease wheat yield (Kayam et $a l ., 2000)$, whereas an increase in temperature and rainfall is found to be negatively related with rice productivity (Saseendran et al., 2000). Peng et al., (2004) estimated a possible $10 \%$ decline of rice productivity from $1 \%$ rise in minimum temperature during dry season. 
In the eastern Indo-Gangetic plains (IGP) of India, rice-wheat-jute (RWJ) cropping system is the most predominant cropping system due to its better adaptability, availability of high yielding varieties and farm mechanization. For over a decade, RWJ yields in high productivity zones have either stagnated or declined. The system is no longer exhibiting increased production with higher input use based on the current climatic pattern. Climate change in terms of increasing temperatures and uncertainty of precipitation is expected to adversely affect the agriculture production (Fisher et al., 2015 and IPCC, 2007). The objective of this study was to analyse the impact of climatic variables on productivity of the jute-rice-wheat cropping system under different fertilizer application rate in alluvial soils of IGP. Aggregated time series data (1972-2012) of long-term fertilizer experiment (LTFE) were used to find out the relationship between rainfall and ambient temperature on productivity of RWJ crops.

\section{Materials and Methods}

The study was conducted over a 40-year period (1972-2012) at Research Farm of Central Research Institute for Jute and Allied Fibre (ICAR-CRIJAF). The study area located in Barrackpore of West Bengal (India), at $88^{\circ}$ $26^{\prime} \mathrm{E}, 22^{\circ} 45^{\prime} \mathrm{N}$ and elevations of $9 \mathrm{~m}$. As per the National Agricultural Research Project classification (NARP 1979) of Agriculture Climatic Zone (India), the RWJ study area belongs to the New Alluvial Zone (WB-4). Climate is humid (rainfall $>1600 \mathrm{~mm}$ ) with a distinct wet monsoon, summer and a cool winter season. Average maximum and minimum temperatures during the experimental period were 36.9 and $19.7{ }^{\circ} \mathrm{C}$, respectively. The soil of study area was sandy loam in texture with slightly alkaline in $\mathrm{pH}$, medium in organic carbon and nitrogen $(\mathrm{N})$, and high in available phosphorus (P) and potassium $(\mathrm{K})$.
During the study period, three crops were grown in rotation, i.e. rice, wheat and jute, under medium land situation. Three treatments of fertilizer management strategies $(0 \% \mathrm{NPK}$, $100 \% \mathrm{NPK}$ and $100 \% \mathrm{NPK}+\mathrm{FYM}$ ) were chosen for crop productivity evaluation on the basis that they are most representative of current practices found in farmer's fields. Chemical fertilizer application rates were based on percentages of the recommended doses for rice, wheat and jute. Field plots of $200 \mathrm{~m}^{2}(20 \times 10 \mathrm{~m})$ with three replications were established for each fertilizer treatments. Jute plant (Corchorus olitorius) as fibre crop was grown in summer season (April-July) followed by rice (Oryza sativa) during rainy season (July-November), while wheat (Triticum aestivum) in winter season (December-March). Seeds of jute and wheat were sown while rice was transplanted as seedlings following standard methods. Three treatments of fertilizer applied for growing RWJ crops is given in Table 1 . Recommended practices of irrigation, weeding and plant protection measures were taken. The experiment was laid out in randomized block design (RBD). The normal climatic parameters at any scale were assumed to be the mean of over a 30-year period (WMO, 1989). Using this criterion, the dataset from 1972 to 2012 was used. Monthly rainfall and temperature data was obtained from the Agricultural Meteorology Unit of ICARCRIJAF Research Farm situated near the experimental plots. The climate corresponds to the RWJ cropping seasons was summer for jute, rainy for rice and winter for wheat. The seasonal mean temperatures and total rainfall were analyzed using the monthly datasets.

\section{Standardized precipitation index (SPI), diurnal temperature range (DTR) and crop productivity index (CPI)}

Standardized precipitation index (SPI) and diurnal temperature range (DTR) are 
important indicators in determining the impact of climate variability on crop yield (Fan et al., 2011). The (SPI) helps to identify and monitor droughts with a minimum long-term $(\geq 30$ years) data requirement at monthly basis (McKee et al., 1993 and Sternberg et al., 2011). The long-term data records fit to probability distribution simulation and transforms into a normal distribution (Edwards and McKee, 1997). SPI was computed from Eq. [1].

$S P I=X_{i}-X / \sigma[1]$

Where, $X_{i}, X$ and $\sigma$ are $i^{\text {th }}$ year precipitation, long-term mean of precipitation and the standard deviation of the mean, respectively. Changes in DTR play an important role in growth and yield of crops (Asseng et al., 2011; Lobell, 2011). Both historical observations and climate models project significant changes in DTR (Easterling et al., 1997; Vose, 2005; Subash and Mohan, 2011). DTR was calculated from Eq. [2].

$\mathrm{DTR}=T_{\max }-T_{\min }[2]$

Where, $T_{\max }$ and $T_{\min }$ are seasonal maximum and minimum temperature, respectively.

Crop productivity is a function of meteorological and soil-crop management practices. To normalize the productivity data, the crop productivity index (CPI) was used to extract the percentage of the technological driven productivity over control treatment. The normalized CPI for the $i^{\text {th }}$ year is calculated from Eq. [3].

$$
C P I_{i}=\left(P f_{i}-P c_{i}\right) \times 100 / P f_{i}[3]
$$

Where, $C P I_{i}$ is the crop productivity index for the $i^{\text {th }}$ year, $P f i$ is the actual productivity under fertilizer treatment for the $i^{\text {th }}$ year, and $P c_{i}$ is the productivity under control (unfertilized treatment) for the $i^{\text {th }}$ year.

\section{Statistical analysis}

Regression analysis approach has been found useful in estimation of crop yield when it is affected by weather factors such as rainfall and temperature (Parry et al., 1988). Relationship between climate variables and crop yield is non-linear as crop growth increases with a rise in temperature upto a certain limit, after that, it may be adversely affected by an increase in the temperature. The same is the case of rainfall impact on crop productivity. Thus, non-linear regression analysis was done using Cobb Douglas production function formula as eq. [4]:

$Y=A X_{i}^{\beta i} \exp ^{\varepsilon}[4]$

Where, $Y$ is a dependent variable (crop yield), $X_{i}$ is a vectors of independent variables included in the regression analysis and $\square$ are parameters to be estimated. $A$ is constant term and $\varepsilon$ is the error with zero mean and constant variance.

Log linear form of Cobb Douglas production function used in the study is given as equation [5]

$\ln Y=\beta+\beta i \sum_{i=1}^{7} \ln X+\varepsilon_{i}[5]$

Where, $\ln Y$ shows yield (tonne per hectare), $X$ is a vector of inputs including traditional inputs and climatic factors. Traditional farm inputs are fertilizer, seed and pesticides used. Climatic variables include rainfall and temperature. $\varepsilon$ is usual error, independently and identically distributed.

\section{Results and Discussion}

\section{Interaction between rainfall and crop yield}

The yearly rainfall data for the 40 years were computed considering the crop growing season length based on planting and harvest 
dates. The developed data explained rainfall variability of $80 \%, 86 \%$ and $1.53 \%$, during monsoon (Aug-Nov), winter (Dec-Mar), and summer (Apr-July) season, respectively. The analysis of jute yield with rainfall $(\mathrm{CV}=22.2)$ was observed and coefficient of correlation between rainfall and yield was 0.48, 0.52 and 0.73 in Control, 100\%NPK and 100\%NPK + FYM treatments. The jute and wheat yield with rainfall was shown positive correlation (Table 2).

The current scenario of jute yield (65\%) was observed with increasing trend of summer rainfall after the year 1992, whereas wheat productivity decreased due to decline in rainfall (Figure 1). Although rice is grown during monsoon months, its production shows a rather weak and insignificant correlation with monsoon rainfall.

\section{Interaction between ambient temperature and crop yield}

Seasonal changes in temperature was assessed to analyse its impact on jute fibre, rice and wheat yield while controlling for other variables at given conditions at the interval of 10 years. Results of these scenarios are presented in Table 3. Results show that jute fibre and rice grain yield increases by $18-20 \%$ and $12-20 \%$, respectively after the year 2002 in all the fertilizer treatments. An increase in temperature by $0.8-1.4^{\circ} \mathrm{C}$ during jute and rice growing season was associated with increase in its yield. Whereas in case of wheat crop, a decline in yield was observed due to decrease in temperature by $1.05^{\circ} \mathrm{C}$ after the year 2002 (Figure 1).

\section{Impact of climate variables on crop yield}

Results of Cobb Douglas production function are given in Table 4. Out of nine coefficients of climatic variables, three coefficients were statistically different from zero. The coefficient of one variable was negative but statistically significant, implying its impact on wheat production. Significance of the model indicated by $F$ value depicted that overall regression model was good for the long-term yield data.

Value of R-square showed that variables included in the model explained variation in jute, rice and wheat yield by $29 \%, 36 \%$ and $57 \%$, respectively due to change in minimum temperature, and $8 \%, 15 \%$ and $65 \%$, respectively due to change in maximum temperature. The maximum impact was in wheat crop due to change in both maximum and minimum temperature. The impact of rainfall was $39 \%, 19 \%$ and $59 \%$ in jute, rice and wheat yield variation, respectively.

\section{Seasonal and annual PI, SPI and DTR}

Seasonal and annual drought and wet frequency analyzed for different season using SPI and DTR are given in Figure 2. The annual SPI was normal (equivalent to -0.5 to +0.5 ) with both dry and wet conditions in a time series. The DTR graph shown a decreasing trend for all season with more warming tendency during winter and rainy compared to summer season. The time-series analysis of DTR for the last decades indicated a decrease in rainy and winter with slight increase during summer season.

The results of the multiple regression correlations between CPI, seasonal SPI and DTR are listed in Table 5. It was observed that the jute and rice productivity index (CPI) and seasonal SPI are significantly correlated $\left(\mathrm{R}^{2}\right)$ at 0.84 and 0.76 in jute and 0.76 and 0.80 in rice, respectively. During winter season, the relationship between seasonal SPI $\left(\mathrm{R}^{2}=0.86\right)$ and DTR $\left(\mathrm{R}^{2}=0.64\right)$ was significant and conforming adverse impact of low rainfall and ambient temperature on the wheat productivity. 
Table.1 Fertilizer doses for growing jute-rice-wheat crop system in new alluvial soils

\begin{tabular}{|c|c|c|c|c|}
\hline \multirow[t]{2}{*}{ Crop } & \multicolumn{3}{|c|}{ Fertiliser applied [FYM:N:P:K $\left(\mathrm{kg} \mathrm{ha}^{-1}\right)$ ] } & \multirow{2}{*}{$\begin{array}{l}\text { Growing } \\
\text { period } \\
\text { (month) }\end{array}$} \\
\hline & $\begin{array}{c}\text { Control } \\
(0 \% \text { NPK })\end{array}$ & $\begin{array}{c}\text { Fertilizer-I } \\
(100 \% \text { NPK })\end{array}$ & $\begin{array}{c}\text { Fertilizer-II } \\
(100 \% \text { NPK+FYM })\end{array}$ & \\
\hline Rice & 00:00:00 & $120: 26: 50$ & $120: 26: 50: 00$ & Aug-Nov \\
\hline Wheat & 00:00:00 & $120: 26: 50$ & $120: 26: 50: 00$ & Dec-Mar \\
\hline Jute & 00:00:00 & $60: 13: 50$ & $60: 13: 50: 10000$ & Apr-Jul \\
\hline
\end{tabular}

Table.2 Relationship between decadal seasonal rainfall and average yield of jute, rice and wheat

\begin{tabular}{|c|c|c|c|c|c|c|c|}
\hline $\begin{array}{l}\text { Fertilizer } \\
\text { treatment }\end{array}$ & Year & 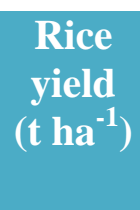 & $\begin{array}{c}\text { Monsoon } \\
\text { rainfall } \\
(\mathrm{mm})\end{array}$ & $\begin{array}{c}\text { Wheat } \\
\text { yield } \\
\left(\mathbf{t} \mathbf{h a}^{-1}\right)\end{array}$ & $\begin{array}{l}\text { Winter } \\
\text { rainfall } \\
(\mathrm{mm})\end{array}$ & $\begin{array}{c}\text { Jute } \\
\text { fibre } \\
\text { yield } \\
\left(\text { t ha }^{-1}\right)\end{array}$ & $\begin{array}{c}\text { Summer } \\
\text { rainfall } \\
(\mathrm{mm})\end{array}$ \\
\hline \multirow[t]{7}{*}{ Control } & 1982 & 1.9 & 518.1 & 0.79 & 356.6 & 1.39 & 950.5 \\
\hline & 1992 & 1.31 & 692.5 & 0.72 & 156.5 & 0.78 & 636.6 \\
\hline & 2002 & 1.38 & 690.7 & 0.60 & 38.8 & 0.58 & 686.3 \\
\hline & 2012 & 1.66 & 1190.6 & 0.65 & 33.1 & 0.7 & 991.7 \\
\hline & Mean & 1.56 & 772.97 & 0.69 & 146.25 & 0.86 & 816.27 \\
\hline & $C V$ & \multicolumn{2}{|c|}{-2.492} & \multicolumn{2}{|c|}{8.885} & \multicolumn{2}{|c|}{23.46} \\
\hline & $\begin{array}{l}\text { Coff. } \\
\text { Corr. }\end{array}$ & \multicolumn{2}{|c|}{-0.04} & \multicolumn{2}{|c|}{0.94} & \multicolumn{2}{|c|}{0.48} \\
\hline \multirow[t]{7}{*}{$100 \%$ NPK } & 1982 & 4.53 & 518.1 & 2.33 & 356.6 & 2.31 & 950.5 \\
\hline & 1992 & 3.36 & 692.5 & 2.26 & 156.5 & 1.94 & 636.6 \\
\hline & 2002 & 2.89 & 690.7 & 2.05 & 38.8 & 1.52 & 686.3 \\
\hline & 2012 & 3.36 & 1190.6 & 1.90 & 33.1 & 1.87 & 991.7 \\
\hline & Mean & 0.54 & 772.97 & 0.96 & 146.25 & 0.48 & 816.27 \\
\hline & $\mathrm{CV}$ & \multicolumn{2}{|c|}{-64.88} & \multicolumn{2}{|c|}{19.51} & \multicolumn{2}{|c|}{22.93} \\
\hline & $\begin{array}{l}\text { Coff. } \\
\text { Corr. }\end{array}$ & \multicolumn{2}{|c|}{-0.43} & \multicolumn{2}{|c|}{0.87} & \multicolumn{2}{|c|}{0.52} \\
\hline \multirow[t]{7}{*}{$100 \% \mathrm{NPK}+\mathrm{FYM}$} & 1982 & 4.49 & 518.1 & 2.34 & 356.6 & 2.28 & 950.5 \\
\hline & 1992 & 3.69 & 692.5 & 2.52 & 156.5 & 2.03 & 636.6 \\
\hline & 2002 & 3.21 & 690.7 & 2.22 & 38.8 & 1.79 & 686.3 \\
\hline & 2012 & 3.59 & 1190.6 & 2.29 & 33.1 & 2.12 & 991.7 \\
\hline & Mean & 3.75 & 772.97 & 2.34 & 146.25 & 2.06 & 816.27 \\
\hline & $\mathrm{CV}$ & \multicolumn{2}{|c|}{-51.54} & \multicolumn{2}{|c|}{5.10} & \multicolumn{2}{|c|}{20.13} \\
\hline & $\begin{array}{l}\text { Coff. } \\
\text { Corr. }\end{array}$ & \multicolumn{2}{|c|}{-0.44} & \multicolumn{2}{|c|}{0.35} & \multicolumn{2}{|c|}{0.73} \\
\hline
\end{tabular}


Table.3 Relationship between decadal change in temperature and average yield of rice, wheat and jute

\begin{tabular}{|c|c|c|c|c|c|}
\hline \multirow[t]{2}{*}{ Crop } & \multirow[t]{2}{*}{ Year } & \multicolumn{3}{|c|}{$\begin{array}{c}\% \text { Change in yield }\left(\mathrm{t} \mathrm{ha}^{-1}\right) \text { under different } \\
\text { fertilizer treatment }\end{array}$} & \multirow{2}{*}{$\begin{array}{c}\text { Change in } \\
\text { temperature } \\
\left({ }^{\circ} \mathrm{C}\right)\end{array}$} \\
\hline & & Control & $100 \%$ NPK & $100 \% \mathrm{NPK}+\mathrm{FYM}$ & \\
\hline \multirow[t]{6}{*}{ Rice } & 1982 & -35.59 & -23.61 & -20.67 & 0.40 \\
\hline & 1992 & -31.05 & -25.82 & -17.82 & -0.20 \\
\hline & 2002 & 5.34 & -13.98 & -13.00 & 0.45 \\
\hline & 2012 & 20.30 & 16.26 & 11.83 & 0.80 \\
\hline & $\mathrm{CV}$ & -0.09 & 0.17 & 0.04 & \multirow[t]{2}{*}{--} \\
\hline & $\begin{array}{l}\text { Coff. } \\
\text { Corr. }\end{array}$ & -0.58 & 0.68 & 0.25 & \\
\hline \multirow[t]{6}{*}{ Wheat } & 1982 & -14.13 & 18.87 & 15.84 & 3.40 \\
\hline & 1992 & -8.86 & -3.00 & 7.69 & 1.30 \\
\hline & 2002 & -16.67 & -9.29 & -11.90 & -1.05 \\
\hline & 2012 & 8.33 & -7.31 & 3.15 & 0.50 \\
\hline & $\mathrm{CV}$ & 0.15 & 0.13 & 0.04 & \multirow[t]{2}{*}{-- } \\
\hline & $\begin{array}{l}\text { Coff. } \\
\text { Corr. }\end{array}$ & 0.98 & 0.37 & 0.22 & \\
\hline \multirow[t]{6}{*}{ Jute } & 1982 & 4.50 & 11.11 & 12.80 & -2.85 \\
\hline & 1992 & -43.88 & -16.00 & -10.96 & 1.10 \\
\hline & 2002 & -25.64 & -21.64 & -11.82 & -1.10 \\
\hline & 2012 & 20.60 & 23.03 & 18.43 & 1.40 \\
\hline & $C V$ & -0.29 & -0.18 & 0.25 & \multirow[t]{2}{*}{--} \\
\hline & $\begin{array}{l}\text { Coff. } \\
\text { Corr. }\end{array}$ & -0.60 & -0.34 & 0.67 & \\
\hline
\end{tabular}

Table.4 Estimates of Cobb Douglas production function

\begin{tabular}{|l|}
\hline \multicolumn{1}{|l|}{ Variables } \\
\hline Ln Summer Temp $p_{\min }$ \\
\hline Ln Rainy Temp min \\
\hline Ln Winter Temp min \\
\hline Ln Summer Temp \\
\hline Ln Rainy Temp \\
\hline Ln Winter Temp \\
\hline Ln Summer Rainfall \\
\hline Ln Rainy Rainfall \\
\hline Ln Winter Rainfall \\
\hline
\end{tabular}

Tempmin-Minimum

Temperature, significant at $5 \%$

\begin{tabular}{|l|l|l|l|l|}
\hline Coefficients & $\begin{array}{l}\text { Standard } \\
\text { Error }\end{array}$ & $\begin{array}{l}\text { t- } \\
\text { ratio }\end{array}$ & $\begin{array}{l}\text { R- } \\
\text { square }\end{array}$ & $\begin{array}{l}\text { F- } \\
\text { value }\end{array}$ \\
\hline 7.2 & -0.18 & 0.72 & 0.29 & 1.06 \\
\hline 23.83 & 0.15 & 1.06 & 0.36 & 1.20 \\
\hline$-1.17^{* *}$ & 0.10 & -1.97 & 0.57 & 1.35 \\
\hline-7.76 & 0.16 & -0.37 & 0.08 & 0.17 \\
\hline-1.12 & 20 & -0.14 & 0.15 & 0.43 \\
\hline $4.87^{* *}$ & 0.07 & 1.10 & 0.65 & 2.79 \\
\hline 1.26 & 0.25 & 1.94 & 0.39 & 1.48 \\
\hline 4.34 & 0.68 & 4.01 & 0.18 & 0.46 \\
\hline $2.12^{* *}$ & 0.13 & 21.6 & 0.59 & 3.36 \\
\hline
\end{tabular}

\section{Temperature,}

Tempmax-Maximum 
Table.5 Regression correlations between CPI, seasonal SPI and DTR

\begin{tabular}{l|l|l|l|} 
Crop & CPI & SPI & DTR \\
\hline Rice & $\mathrm{y}=-0.1468 \mathrm{x}+$ & $\mathrm{y}=0.0896 \mathrm{x}-$ & $\mathrm{y}=-0.0167 \mathrm{x}+33$ \\
& 292.54 & 178.89 & $\left(\mathrm{R}^{2}=0.09\right)$ \\
& $\left(\mathrm{R}^{2}=0.76\right)$ & $\left(\mathrm{R}^{2}=0.80\right)$ & \\
\hline \multirow{2}{*}{ Wheat } & $\mathrm{y}=0.0085 \mathrm{x}-$ & $\mathrm{y}=-0.0925 \mathrm{x}+$ & $\mathrm{y}=0.0369 \mathrm{x}-$ \\
& 16.933 & 184.76 & 74.23 \\
& $\left(\mathrm{R}^{2}=0.01\right)$ & $\left(\mathrm{R}^{2}=0.86\right)$ & $\left(\mathrm{R}^{2}=0.64\right)$ \\
\hline \multirow{2}{*}{ Jute } & $\mathrm{y}=0.0921 \mathrm{x}-$ & $\mathrm{y}=-0.1468 \mathrm{x}+$ & $\mathrm{y}=0.0085 \mathrm{x}-$ \\
& 183.69 & 292.54 & 16.93 \\
& $\left(\mathrm{R}^{2}=0.84\right)$ & $\left(\mathrm{R}^{2}=0.76\right)$ & $\left(\mathrm{R}^{2}=0.01\right)$
\end{tabular}

Fig.1a, 1b, 1c Yield of rice, wheat and jute vis-à-vis rainfall and temperature distribution
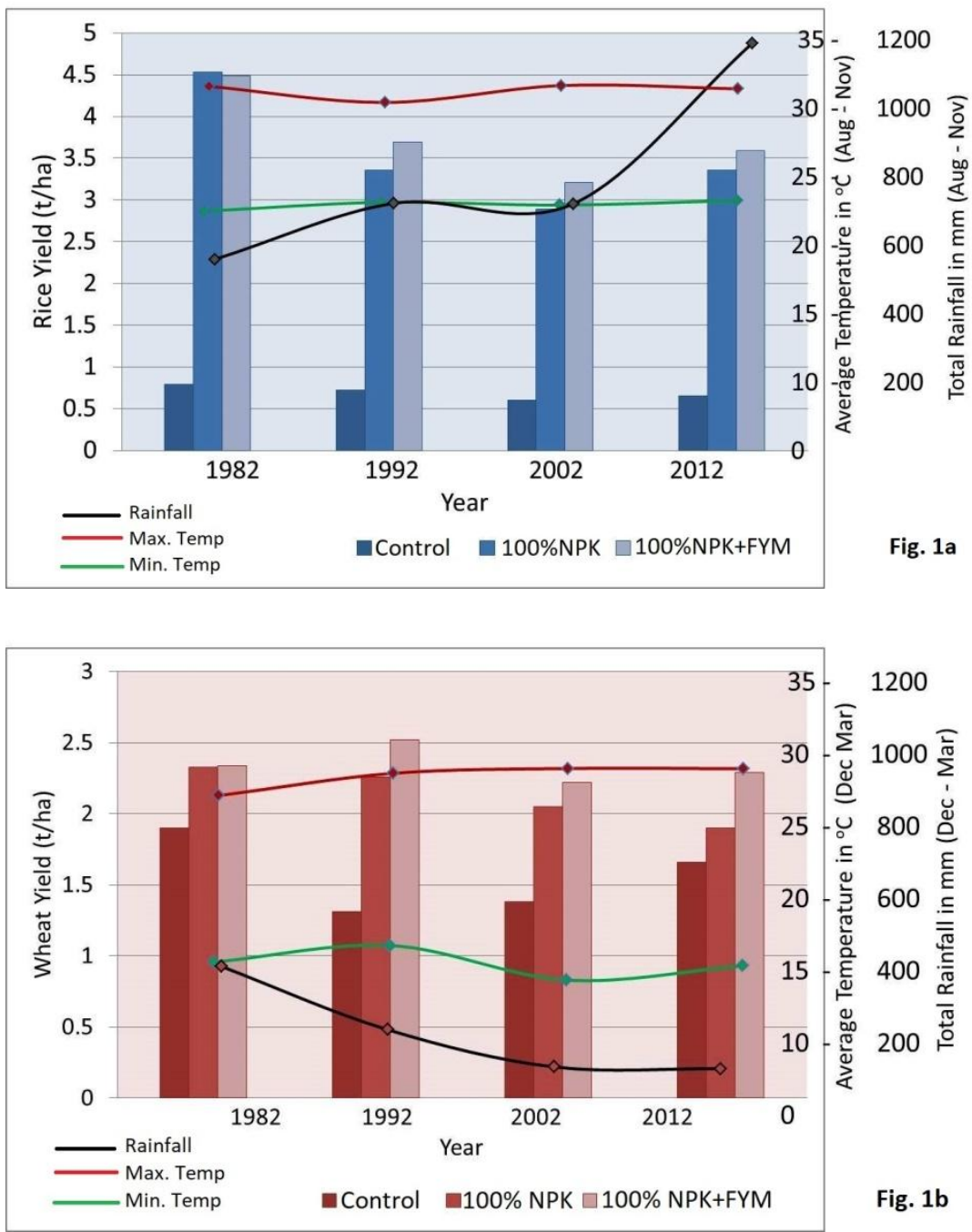


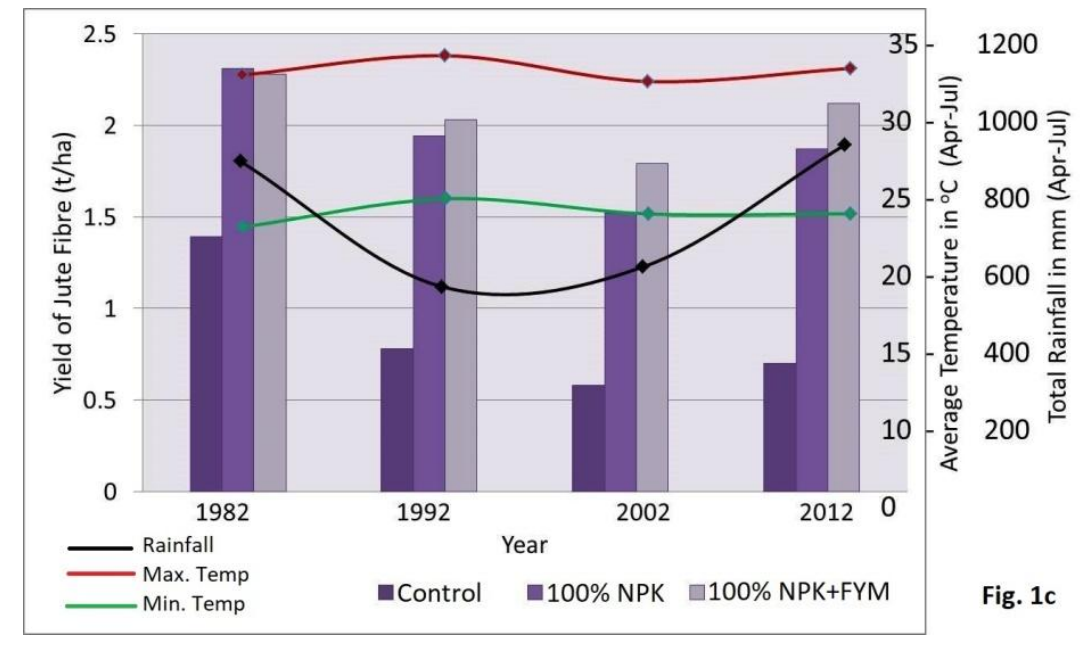

Fig.2 Standardized Precipitation Index (SPI) and temporal Diurnal Temperature Range (DTR) under jute-rice-wheat cropping system

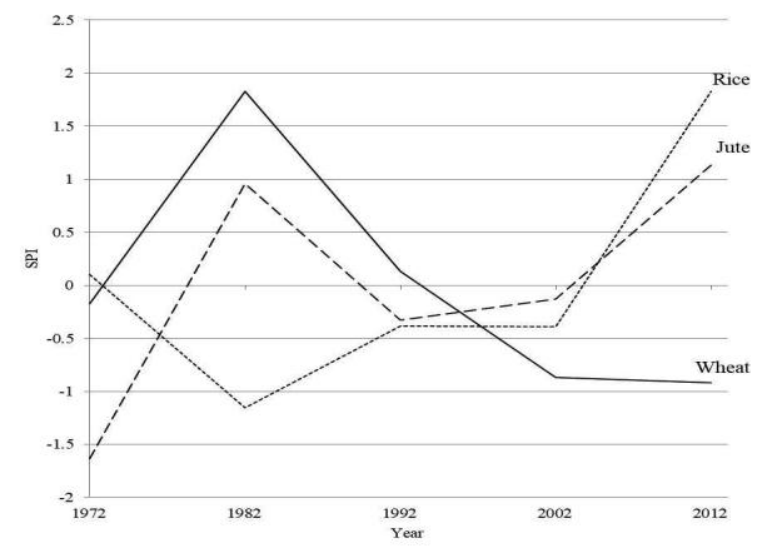

This study examines climate variability and its impacts on rice, wheat and jute productivity under long-term fertilizer treated alluvial soils. The seasonal rainfall trend shows an increasing tendency during summer and rainy season but decreased significantly during winter season. Similar trend was also reported in the monthly distribution of rainfall during southwest monsoon in Indo-Gangetic region for a long duration (Subash and Mohan, 2011). However, there are distinct differences in the trend for increasing rainfall after the year 2002. The seasonal temperature also reports an increasing tendency during summer and rainy season, and decreasing tendency during winter. The difference between base decade (1972-1982) and recent decade (2002-2012) shows a significant change of the rainfall. Winter wheat

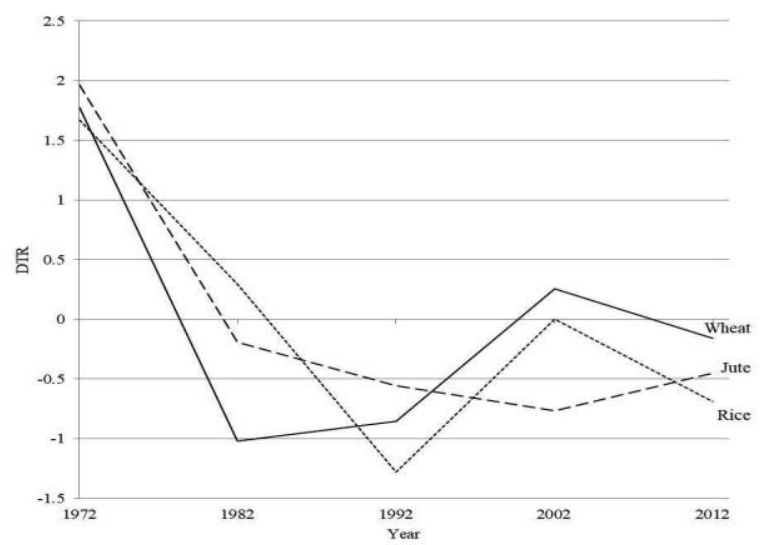

was affected most due to changing pattern of rainfall and temperature. It is important to note that winter rainfall shows shrinking pattern and could be a concerning factor for wheat productivity. The increase in jute productivity was mainly associated with increased rainfall and ambient temperature. Rice productivity shows a weak and insignificant yield increase due to change in rainfall. The estimates of Intergovernmental Panel on Climate Change (IPCC) for year 2050 indicate that changing rainfall patterns and increasing temperature will possibly decline rice and wheat production (Cancelliere et al., 2007). Drought stress due to changing rainfall pattern can cause a loss in annual crop production of upto $40 \%$ in South and Southeast Asia (IRRI, 2009). Long-term SPI values are indicative of distinct wet and dry 
events but may not necessarily show a definite trend. It is observed that the winter period was more vulnerable to drought conditions compared to the other season. The downward trend of DTR is related to change in minimum temperatures compared to maximum temperatures (Wang et al., 2009).

This study elucidates seasonal and annual rainfall and temperature variability to assess seasonal trends in three crop cycles for five decades (1972-2012). An increasing trend in the total seasonal rainfall was observed, particularly during the summer and monsoon season. However, it was decreased to $33 \mathrm{~mm}$ (2012) from $356 \mathrm{~mm}$ (1982) during the dry winter season. Additionally, maximum $\left(0.80{ }^{\circ} \mathrm{C}\right.$ per decade) and minimum (to $1.04{ }^{\circ} \mathrm{C}$ per decade) temperatures indicate an increase of dry season when compared to base year (1972). The regression analysis between crop productivity and climate variation showed a good degree of response. SPI and DTR captured the yield variability in all three crops. The yield variability was maximum (57-65\%) in case of wheat crop due to low rainfall and decrease in night temperature. It was also noted that impact of rainfall variability did not affect rice yield significantly but benefited jute productivity during summer season. To alleviate the risk of climate change in jute and wheat production, it is important to adjust the sowing/ transplanting period in corresponding to future climate trends. This study may help to develop climate smart agricultural practices through appropriate, environmentally sound and economically feasible technologies. It is anticipated that such analysis could serve as policy support tool while planning climate change adaptation strategies.

\section{Acknowledgements}

The author(s) gratefully acknowledge Director, ICAR-CRIJAF, Barrackpore (India) for his kind cooperation and providing long term fertilizer experiment reports and meteorological data to carry out this work.

\section{References}

Asseng, S., Foster, I. and Turner, N.C. 2011. The impact of temperature variability on wheat yields. Global Change Biology, 17: 997-1012.

Cancelliere, A., Di Mauro, G., Bonaccorso, B. et al., 2007. Drought forecasting using the standardized precipitation index. Water Resource Management, 21: 801-19.

Easterling, D.R., Horton, B., Jones, P.D., Peterson, T.C., Karl, T.R., Parker, D.E., Salinger, M.J., Razuvayev, V., Plummer, N., Jamason, P. and Folland, C.K. 1997. Maximum and minimum temperature trends for the globe. Science, 277: 364367.

Edwards, D.C. and McKee, T.B. 1997. Characteristics of $20^{\text {th }}$ century drought in the United States at multiple timescales. Climatology Report, vol. 92, Colorado State University, Fort Collins.

Eze, S.O., and Afolabi and Bola Abdulhamid 2013. Effect of ambient temperature and rainfall on rice production in the Gambia: A case study of the Central River Region. Agriculture Science Developments, 2(9): 79-83.

Fan, Z., Bräuning, A., Thomas, A., et al., 2011. Spatial and temporal temperature trends on the Yannan Plateau (Southwest China) during 1961-2004. International Journal of Climatology, 31:2078-2090.

Fisher, M., Abate, T., Lunduka, R.W., Asnake, W., Alemayehu, Y. and Madulu, R.B.2015. Drought tolerant maize for farmer adaptation to drought in subSaharan Africa: determinants of adoption in eastern and southern Africa. Climate Change, 133: 283-99.

Hussain, S. S. and Mudassar M. 2007. Prospects for wheat production under changing climate in mountain areas of Pakistan-An econometric analysis. Agriculture System, 94: 494-501.

IPCC. 2007. Summary for policymakers. In: Solomon S, Qin D, Manning M, et al., editors. Climate change 2007: the 
physical science basis, contribution of working group I to the forth assessment report of the intergovernmental panel on climate change. Cambridge University Press, Cambridge.

IRRI 2009.Climate change ready rice. Retrieved from http://irri.org/ourscience/bettervarieties/climate-readyrice\%23Drought.

Kayam, Y., Ozsoy, U., Lomas, J., Oden, O., Mandel, M. and Gurbuz, M. 2000. The impact of climatic change on wheat production of Aegean region in Turkey: The effect of a reduction of rainfall and the increase of temperature on wheat yields. Retrieved from http://www.fao.org/sd/climagrimed/pdf/w s01_26.pdf

Lobell, D.B. and Field, C.B. 2007. Global scale climate-crop yield relationships and the impacts of recent warming. Environmental Research Letters, 2: 004000.

McKee, T.B., Doesken, N.J., \& Kleist, J. (1993). The relationship of drought frequency and duration to time scales. In: Proceeding of the 8th conference on applied climatology. American Meteorological Society, Boston.

Parry, M. L., Carter, T. R. and Konjin, N. T. 1988. The impact of climatic variations on agriculture. assessments in semi-arid regions. Kluwer Academic Publishers.

Peng, S., Huang, J., Sheehy, J. E., Laza, R. C., Visperas, R. M., Zhong, X., Centeno, G. S., Khush G. S. and Cassman, K. G. 2004. Rice yield decline with higher night temperature from global warming. Proceedings of the National Academy of Sciences, 101: 9971-9975.
Saseendran, S. A., Singh, K. K., Rathore, L. S., Singh, S. V. and Sinha, S. K. 2000. Effects of climate change on rice production in the tropical humid climate of Kerala, India. Climate Change, 44: 495-514.

Sternberg, T., Thomas, D. and Middleton, N. 2011. Drought dynamics on the Mongolian steppe, 1970-2006. International Journal of Climatology, 31: 1823-1830.

Subash, N. and Mohan, H.S.R. 2011. Trend detection in rainfall and evaluation of standardized precipitation index as a drought assessment index for rice-wheat productivity over IGR in India. International Journal of Climatology, 31: 1694-1709.

Sushila, K. 2001. Bioeconomic modeling of climate change on crop production in India. Retrieved from www.ecomod.org/files/papers/370.pdf.

Vose, R.S., Easterling, D.R. and Gleason, B. 2005.Maximum and minimum temperature trends for the globe: an update through 2004. Geophysical Research Letters, 32:L23822.

Wang, L., Huang, R.H., Gu, L., et al., 2009. Interdecadal variations of the East Asian winter monsoon and their association with quasi-stationary planetary wave activity. Journal of Climate, 22:48604872 .

WMO.1989. Calculation of monthly and annual 30-year standard normal. WCDP, No. 10, WMO-TD/No. 341. World Meteorological Organization, Geneva.

\section{How to cite this article:}

Singh, A.K., D. Barman, M.S. Behera, S.P. Mazumdar, A.R. Saha and Kundu, D.K. 2018. Impact of Climate Change on Productivity of Tropical Rice-Wheat-Jute System under Long Term Fertilizer Management in Alluvial Soils. Int.J.Curr.Microbiol.App.Sci. 7(11): 1623-1632. doi: https://doi.org/10.20546/ijcmas.2018.711.184 